\title{
Reproductive output of Macoma balthica populations in relation to winter-temperature and intertidal-height mediated changes of body mass
}

\author{
P. J. C. Honkoop*, J. van der Meer \\ Netherlands Institute for Sea Research (NIOZ), PO Box 59, 1790 AB, Den Burg, Texel, The Netherlands
}

\begin{abstract}
To study relationships between environmental conditions and reproductive output, numbers and sizes of eggs produced by the intertidal bivalve Macoma balthica were determined after the winters of 1995 and 1996 at 3 stations at different intertidal levels in the Dutch Wadden Sea. At all field stations significantly more (1.5 to 7 times) eggs were produced after the cold winter of 1996 than after the mild winter of 1995 when individual body masses were lower than in early 1996. At 2 stations the eggs were also significantly larger in 1996. In both years, eggs were larger at low than at high mud flats. Egg size was significantly positively correlated with adult body mass in the preceding summer (when gametogenesis takes place). Egg numbers, on the other hand, were only significantly positively correlated with the body mass just prior to spawning. Below a body mass of $5.6 \mathrm{mg}$ ash-free dry mass per $\mathrm{cm}^{3}$ (cubic shell length), $M$. balthica did not produce any eggs. Above this body mass, egg numbers increased by about 7700 per mg ash-free dry mass at a shell length of $15 \mathrm{~mm}$.
\end{abstract}

KEY WORDS: Macoma balthica Bivalve Body mass Egg number - Egg size - Reproductive output

\section{INTRODUCTION}

Animals first and foremost use the energy from food intake for maintenance of both somatic and reproductive tissue. If a surplus of energy is available, it is used for growth and reproduction (Kooijman 1993). Thus, the reproductive output of animals will vary with changing environmental conditions, such as food availability (affecting energy gain) and temperature (affecting energy gain and energy expenditure).

The bivalve Macoma balthica (L.), a common species at all intertidal heights in the Dutch Wadden Sea, shows differences in growth rate at different intertidal levels (Beukema et al. 1977). M. balthica is a facultative filter feeder, which means that food can be collected from the water column as well as from the sediment surface (Brafield \& Newell 1961, Hummel 1985, Ólafsson 1986). Although benthic food densities are relatively high at high tidal levels (Cadée \& Hegeman

•E-mail: honkoop@nioz.nl
1977), growth rate is low, probably as a consequence of the shorter immersion time, allowing only short daily periods of filter feeding. Similar observations were made in $M$. balthica populations on the Canadian Atlantic East coast (Harvey \& Vincent 1990, 1991). The effects of food availability on growth of $M$. balthica have been described in several studies (Green 1973, Hummel 1985, Beukema \& Desprez 1986), but so far reports on reproductive output (i.e. egg size and egg numbers) have only concerned egg size measured in dissected gonads and total reproductive-tissue mass (Harvey \& Vincent 1989, 1991, Harvey et al. 1993). All studies, except that of Green (1973), point out that growth of both somatic and reproductive tissues is maximal at the lower intertidal levels. Therefore, reproductive output would be highest at low tidal levels (Harvey \& Vincent 1991).

Growth of Macoma balthica is restricted to a range of water temperatures of 4 to $16^{\circ} \mathrm{C}$ in spring (Beukema et al. 1985), with optimum growth at $10^{\circ} \mathrm{C}$ (De Wilde 1975). In winter, masses decline and mass loss is more 
rapid at high than at low temperatures (Zwarts 1991, Honkoop \& Beukema 1997). Effects of temperature on gonadal development are largely unknown. Some studies indicate that winter temperatures affect recruitment in the subsequent summer, with higher winter temperatures resulting in lower recruitment (Beukema 1982, 1992). In several species of intertidal bivalves, severe winters are also followed by high recruitment (Kristensen 1957, Beukema 1982, 1992, Möller \& Rosenberg 1983, Jensen 1992). Such differences in recruitment may have been caused, at least partially, by lower fecundity of adult populations after mild than after cold winters.

The objectives of this study were to estimate the reproductive output (in terms of egg size and egg numbers) of Macoma balthica populations living at different intertidal levels in the Dutch Wadden Sea and to relate these outputs to immersion times and to water temperatures during winter. Size and numbers of released eggs were estimated at various field stations after 2 winters with different characters, the mild winter of 1994-1995 and the cold winter of 1995-1996. As shown in Honkoop \& Beukema (1997), body mass of $M$. balthica prior to spawning can be influenced by manipulation of immersion time and water temperature during the preceding months. Thus, the body mass values of the various studied populations of $M$. balthica differed in a predictable way: high at low levels and in 1996, low at high levels and in 1995. Reproductive output could thus be related to the consistently differing body mass values of adult $M$. balth$i c a$, both collected in the field and obtained from experimentally manipulated groups (Honkoop \& Van de Meer 1997).

\section{MATERIALS AND METHODS}

Macoma balthica. Field observations on egg numbers and egg sizes in Macoma balthica were made at 3 stations (Stn A: low, Stn B: intermediate, and Stn C: high) in the intertidal zone at Balgzand, a tidal-flat area in the westernmost part of the Dutch Wadden Sea. As in earlier studies, body mass values at a standard shell length tended to increase with decreasing tidal level. Exact locations and some environmental properties of the stations are described in an earlier paper (Honkoop \& Beukema 1997).

At the end of March (in 1995 and 1996), immediately before spawning at a water temperature of 7 to $9^{\circ} \mathrm{C}$, about 500 Macoma balthica, ranging from 13 to $18 \mathrm{~mm}$, were collected at each of the 3 stations. Per site, the body mass index ( $\mathrm{BMI}, \mathrm{mg} \mathrm{cm}^{-3}$ ), defined as ash-free dry mass divided by cubic shell length, was determined directly after collection in 25 unparasitized indi- viduals. BMI values were also determined in August 1994 and August 1995 as part of a long-term data series (J. J. Beukema \& R. Dekker pers. comm.).

Spawning. Directly after collection in March, all specimens, except those we used to determine the BMI, were placed in small buckets filled with sediment and allowed to burrow. The buckets were placed in a refrigerator at $4^{\circ} \mathrm{C}$. The next morning, 100 Macoma balthica from each station were individually placed in $100 \mathrm{~cm}^{3}$ beakers filled with aerated seawater with a temperature of $12^{\circ} \mathrm{C}$. After $30 \mathrm{~min}$ this water was replaced by fresh aerated $12^{\circ} \mathrm{C}$ seawater. Then, mostly within $10 \mathrm{~min}$, spawning began; usually males first. Over $4 \mathrm{~h}$ the water was changed every $45 \mathrm{~min}$. After a few hours of this treatment no further specimens could be induced to spawn. Therefore, experiments were terminated after $4 \mathrm{~h}$ and all $M$. balthica were replaced by fresh individuals and the procedure started again. This procedure was repeated until enough material had been collected to estimate egg size and egg numbers with sufficient precision.

Egg diameters and egg numbers. Freshly spawned eggs were multiform because the eggs in the gonads were tightly clumped together. Within $30 \mathrm{~min}$ after release, the shape of most of the eggs had changed to a round or only slightly aspherical shape. After $30 \mathrm{~min}$, a few hundred of the eggs of each female were removed with a capillary pipette, placed on a flat microscopic slide and photographed twice. ISO 100 colour slides were used with a Zeiss M-35 camera fitted to a Zeiss stereo microscope at $63 \times$ magnification. The eggs were all returned to the remainder of the clutch from which they had been removed

From the eggs of each female, 2 dia positive slides were made. These slides were projected on a transparent screen with the slide projector placed at a fixed distance. Opposite the projector and at the backside of the screen the longest and shortest axes of 30 sharply focused eggs per female were measured with a Mitutoyo $C D-15 D$ digital calliper to the nearest $0.01 \mathrm{~mm}$. Using a Mitutoyo DP-1 HS digimatic Mini Processor as interface, the calliper was connected to a computer which stored all measurements directly. Egg size was defined as the mean of the lengths along the longest and shortest axes.

After the females finished spawning, generally within $1 \mathrm{~h}$ after spawning had begun, all eggs were removed with a Finn pipette to a known volume, $40 \%$ formalin was added to a final concentration of $4 \%$ and the thus preserved eggs were stored until counting. After stirring, a known aliquot, containing 100 to 200 eggs, was placed on a grid and eggs were counted under a stereo microscope. For each female this was repeated at least 5 times. From these counts, the total number of eggs spawned by each female was calculated. 
Each female that had spawned was numbered, and for a period of 2 to $3 \mathrm{wk}$ these females were forced to release all their eggs; they were stored each night at $4{ }^{\circ} \mathrm{C}$ and each morning the females were subjected to a new temperature shock when they were placed in $12^{\circ} \mathrm{C}$ seawater, after which the water was changed several times a day. After 2 to $3 w k$, the shells were opened and gonads were checked to see whether they were empty (or only a few residual eggs were left) Only the cumulative egg counts from (nearly) empty animals were used to calculate mean egg production.

\section{RESULTS}

\section{Spatial and temporal differences in body mass}

Mean body mass values of the 3 groups of Macoma balthica as observed in March, just prior to spawning, are listed in Table 1 along with the mean values observed in the same populations in the preceding August. After the cold winter of 1995-1996, with a mean January-March water temperature of $-0.1^{\circ} \mathrm{C}$ (measured daily in the nearby Marsdiep inlet), the body mass at all 3 stations was higher and the mass loss smaller than after the mild winter of 1994-1995. which had a mean January-March water temperature of $5.1^{\circ} \mathrm{C}$. Two factors contributed to the higher body mass prior to spawning in 1996. The first was the higher initial body mass value (August value) and the second was the lower loss of body mass during autumn and winter During the mild 1994-1995 autumn-winter period, more $\left(3.8\right.$ to $6.9 \mathrm{mg} \mathrm{cm}^{-3}$ ) of the initial body

Table 1 Macoma balthica Successive mean values of body mass index (BMI) of $M$. balthica as observed at each of 3 field stations in August (i.e. 8 mo before spawning) and in March just prior to spawning in 2 years (1994-1995 and 1995/1996). Mass loss ( $\mathrm{mg} \mathrm{cm}^{-3}$ ) is the proportion of mass loss between August and March. BMI ( $\mathrm{mg} \mathrm{cm}^{-3}$ ) is ash-free dry mass divided by cubic shell length. Each mean value was determined from at least 25 specimens. Tidal level $(\mathrm{cm})$ is shown relative to mean tidal level

\begin{tabular}{|lrccc|}
\hline Stn & Tidal level & BMI Aug & BMI Mar & BMI loss \\
\hline $1994-1995$ & & & & \\
A & -20 & 14.4 & 7.8 & 6.6 \\
B & 0 & 13.8 & 6.9 & 6.9 \\
C & +30 & 10.0 & 6.2 & 3.8 \\
Mean & & 12.7 & 7.0 & 5.8 \\
1995-1996 & & & & \\
A & -20 & 16.1 & 10.6 & 5.5 \\
B & 0 & 15.3 & 9.9 & 5.4 \\
C & +30 & 15.0 & 12.4 & 2.6 \\
Mean & & 15.5 & 11.0 & 4.5 \\
\hline
\end{tabular}

mass was lost than during the cold 1995-1996 autumnwinter period (2.6 to $5.5 \mathrm{mg} \mathrm{cm}^{-3}$ ).

The order of BMI values at the 3 stations was similar in August in the 2 years, which is consistent with the long-term observations (J. J. Beukema pers. comm.). After the winter of 1994-1995. BMI values were also highest at the station lowest in the intertidal area ( $\operatorname{Stn} \mathrm{A}$ ), and lowest at the station highest in the intertidal area (Stn C). The BMI of Stn B, at an intermediate intertidal level, was intermediate. Rankings after the cold winter of 1995-1996, however, were different, with an exceptionally high body mass value at Stn C, at the higher intertidal level. The other stations showed lower BMI values, of which the BMI of Stn A was again higher than that at Stn B.

The loss of body mass during the autumn-winter periods differed per station. Mass losses were relatively high at the 2 lower stations ( $A$ and $B$ ) and low at the higher tidal-level station (C).

\section{Spatial and temporal differences in egg sizes}

The mean size of the produced eggs differed between stations. In both years, the largest eggs were produced at $\operatorname{Stn} \mathrm{A}$, the lowest station. The smallest eggs were produced at $S \ln C$, the station at the highest intertidal level. At the intermediate tidal level (Stn B), the eggs had an intermediate diameter (Fig. 1). These differences were highly significant (ANOVA, $F_{\mathrm{s}|2,181|}=$ 21.8, $\mathrm{p}<0.001)$. The differences in size between the 2 years were also significant (ANOVA, $F_{\mathrm{s}|1,181|}=6.5$, $p<0.05$ ); eggs produced at Stns $B$ and $C$ were larger

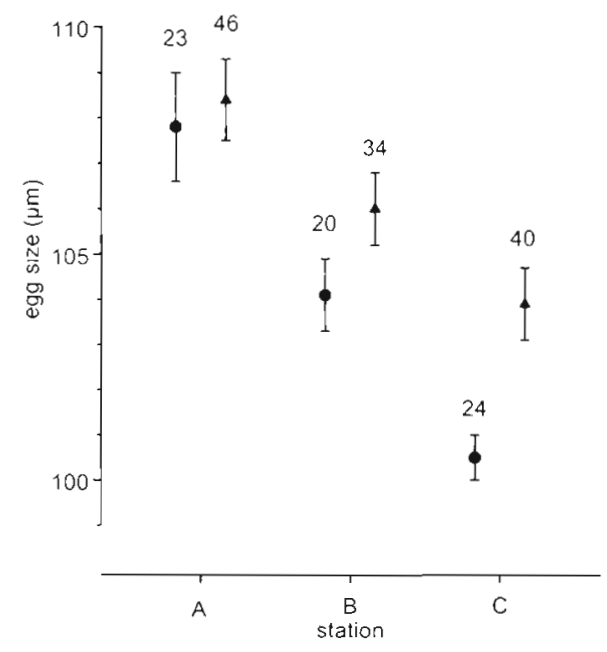

Fig. 1. Macoma balthica. Mean diameter $( \pm S E)$ of eggs produced at the 3 different Balgzand stations: A (low), B (intermediate), and $C$ (high) in 1995 ( $\bullet$ and 1996 (४). Numbers above error bars indicate the number of females from each of which the diameter of 30 eggs was measured 


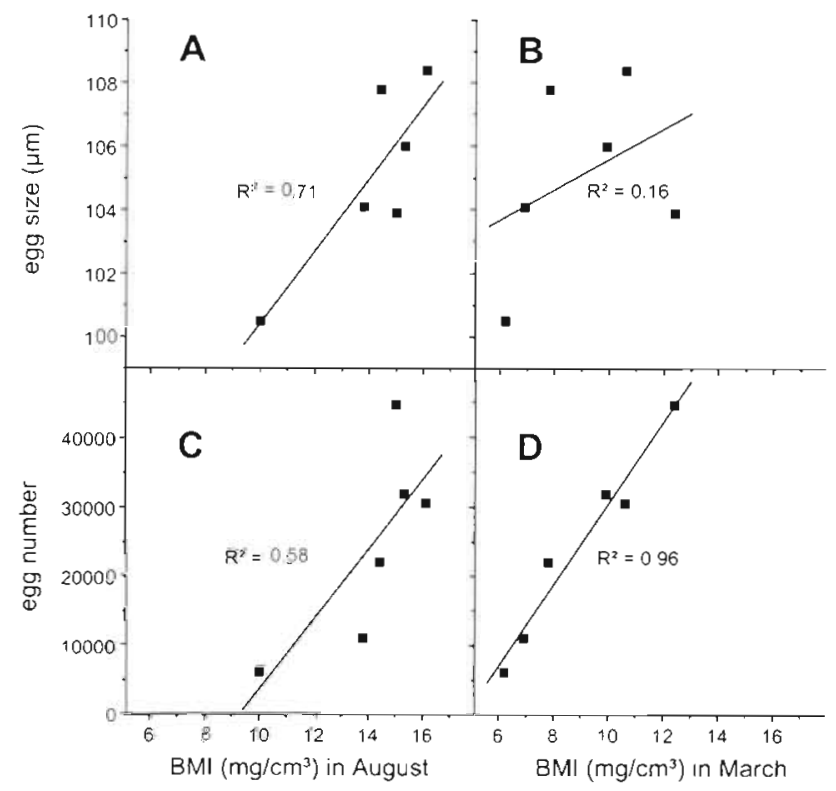

Fig. 2. Macoma balthica. Relationship between egg size after spawning in April and body mass index (BMI) in (A) the preceding August and (B) March just prior to spawning; and, the relationship between number of eggs produced in April and $\mathrm{BMI}$ in (C) the preceding August and (D) March just prior to spawning. Egg numbers are corrected for $M$. balthica of standardized shell length $(15 \mathrm{~mm})$. BMI is ash-free dry mass divided by cubic shell length

after the cold winter of 1996 than after the mild winter of 1995. Interaction between site and year was not significant (ANOVA, $F_{s, 2,181\}}=1.1, \mathrm{p}>0.1$ )

The relationships between mean egg size and BMI values 8 mo prior to spawning (August) and just prior to spawning (March) are shown in Fig. 2A, B. The regression between egg size and $\mathrm{BMI}$ was closer for the BMI values of the preceding August $\left(R^{2}=0.71, p<\right.$ 0.05 ; Fig. 2A) than for the BMI values observed just prior to spawning $\left(\mathrm{R}^{2}=0.16, \mathrm{p}>0.1\right.$; Fig. $\left.2 \mathrm{~B}\right)$.

\section{Spatial and temporal differences in egg numbers}

An allometric relationship between the number of eggs produced per individual female and the shell length of the female may be assumed, which after logtransformation looks in its most general form like this:

$$
\begin{aligned}
\log \left(\mathrm{n}_{i j k}\right)= & {\left[\mu+\alpha_{i}+\beta_{1}+(\alpha \beta)_{i j}\right]+} \\
& {\left[\gamma+\phi_{j}+\varphi_{j}+[\phi \varphi)_{i j}\right] \times \log \left(I_{i j k}\right)+\varepsilon_{j j k} }
\end{aligned}
$$

where $\sum_{1} \alpha_{3}=\sum_{1} \beta_{j}=\sum_{1} \phi_{i}=\sum_{j} \varphi_{i}=0, \sum_{j}(\alpha \beta)_{i j}=\sum_{j}(\phi \varphi)_{i j}=0$ for each $j_{1} \sum_{j}(\alpha \beta)_{i j}=\Sigma_{j}(\phi \varphi)_{i j}=0$ for each $i$, and $n_{i j k}$ is the number of produced eggs at site $i$, in year $j$, by female $k_{1} \mu$ is the common intercept, $\alpha_{1}$ is the site deviation in intercept, $\beta$, is the year deviation in intercept, $(\alpha \beta)_{i j}$ is an interaction term, $\gamma$ is the common slope, $\phi_{i}$ is the site
Table 2. Homogeneity-of-slopes test of the relationship between egg production versus shell length among sites and years and test of the hypothesis that the common slope equals 3. ns: $p>0.05$

\begin{tabular}{lcccc|}
\hline Model & df & SS & F-ratio & p \\
\hline Different slopes & 64 & 4.064 & 1.37 & $\mathrm{~ns}$ \\
Common slopes & 69 & 4.479 & $<1$ & $\mathrm{~ns}$ \\
Slope $=3$ & 70 & 4.499 & & \\
\hline
\end{tabular}

deviation in slope, $\varphi$, is the year deviation in slope, $(\phi \varphi)_{i j}$ is an interaction term, $\varepsilon_{i j k}$ is the error term, and $I_{i j k}$ is the shell length at site $i_{1}$ in year $j$, of female $k$. The significance of the $\phi, \varphi$, and $(\phi \varphi)$ terms was tested first. The so-called homogeneity-of-slopes test revealed that the terms were not significantly different from zero. Thus, the slopes of shell length versus egg production at the 3 sampling sites in the 2 years could be replaced by a common slope $\gamma$ (Table 2), leading to the following simplified model:

$$
\log \left(\mathrm{n}_{i j k}\right)=\left[\mu+\alpha_{i}+\beta_{j}+(\alpha \beta)_{i j}\right]+\gamma \times \log \left(l_{i j k}\right)+\varepsilon_{i j k}
$$

The estimated common slope of $\gamma=2.906$ was not significantly different from the value of $\gamma=3$ (Table 2). This results in the further simplified model:

$$
\log \left(c_{i j k}\right)=\mu+\alpha_{i}+\beta_{j}+(\alpha \beta)_{i j}+\varepsilon_{i j k}
$$

where $\log \left(c_{i j k}\right)=\log \left(n_{i j k}\right)-3 \times \log \left(l_{i j k}\right)$ or $c_{i j k}=n_{i j k} \times$ $\left(l_{i j k}\right)^{-3}$, thus representing the number of eggs per unit of shell volume

Analysis of variance revealed that site, year and the interaction between site and year all contributed significantly $(\mathrm{p}<0.05)$ to the variation of $\log \left(C_{j j k}\right)$. More eggs were produced in 1996 than in 1995, but the orders of egg number per site differed between 1995 $(A>B>C$ ) and 1996 ( $C>A>B)$ (Table 3 ). Although the size ranges of the selected animals were similar in the 6 groups, the mean shell length of 1 group of females (Stn C in 1995) was significantly smaller ( $p<$ 0.05 ) (Table 3). Therefore, it made sense to recalculate the egg numbers for a Macoma balthica with a standardized shell length; the back-transformed estimate of $\log \left(C_{i j k}\right)$ was multiplied by $15^{3}$ to obtain an estimate of egg numbers produced by a $M$. balthica with a standardized shell length of $15 \mathrm{~mm}$ (last column of Table 3)

\section{Egg numbers in relation to body mass}

The estimated egg numbers of standardized Macoma balthica of $15 \mathrm{~mm}$ shell length (Table 3) were plotted against BMI values of both the preceding summer (August) and just prior to spawning (March) 
Table 3. Macoma balthica. Number ( $\mathrm{n}$ ) and mean shell length of empty-spawned females and the actual mean ( \pm SD) numbers of eggs produced and mean ( \pm SD) egg production recalculated for a standardized $M$. balthica of $15 \mathrm{~mm}$ shell length at each of the 3 sites (A, B, and C) in 1995 and in 1996. The mean shell length was similar between sites and years $(p>$ 0.1 ), except for the smaller value at $\mathrm{Stn} C$ in 1995

\begin{tabular}{|c|c|c|c|c|}
\hline \multirow[t]{2}{*}{ Stn } & \multirow[t]{2}{*}{$\mathrm{n}$} & \multirow{2}{*}{$\begin{array}{c}\text { Shell } \\
\text { length } \\
\text { (mm) }\end{array}$} & \multicolumn{2}{|c|}{ Numbers of eggs produced } \\
\hline & & & $\begin{array}{c}\text { Real } \\
\text { observations }\end{array}$ & $\begin{array}{l}\text { Standard } \\
\text { M. balthica }\end{array}$ \\
\hline \multicolumn{5}{|c|}{1995} \\
\hline A & 7 & $17.0 \pm 1.0$ & $32884 \pm 8339$ & $22115 \pm 5496$ \\
\hline B & 12 & $16.7 \pm 1.7$ & $15953 \pm 13104$ & $11082 \pm 9765$ \\
\hline $\mathrm{C}$ & 14 & $14.3 \pm 2.1$ & $4744 \pm 2387$ & $6199 \pm 4256$ \\
\hline \multicolumn{5}{|c|}{1996} \\
\hline A & 18 & $16.7 \pm 2.4$ & $44950 \pm 33612$ & $30587 \pm 18886$ \\
\hline B & 14 & $15.1 \pm 1.3$ & $33696 \pm 16485$ & $31909 \pm 11322$ \\
\hline $\mathrm{C}$ & 11 & $16.4 \pm 1.4$ & $57780 \pm 20887$ & $44782 \pm 16952$ \\
\hline
\end{tabular}

(Fig. 2C, D). In contrast to the observed relation of BMI versus egg size (Fig. 2A, B), egg numbers were more closely related to the March BMI values $\left(R^{2}=0.96, p<\right.$ 0.01; Fig. 2D) than to the preceding August BMI values $\left(R^{2}=0.58, p>0.05 ;\right.$ Fig. $\left.2 C\right)$. The best linear fit for the field data $(n=6)$ of the relation between the egg number of a $15 \mathrm{~mm} \mathrm{M}$. balthica and its BMI just prior to spawning was

$$
\text { egg number }=5858 \times \mathrm{BMI}-28087
$$

By manipulation of temperature and tidal level, several groups of $M$. balthica with different BMI values prior to spawning were obtained experimentally (Honkoop \& Beukema 1997, Honkoop \& Van der Meer 1997). Using egg numbers and BMI values of these $M$. balthica (after recalculation to a standardized shell length of $15 \mathrm{~mm})$ the best linear fit $\left(\mathrm{R}^{2}=0.46, \mathrm{p}<0.01\right)$ for the experimental data $(\mathrm{n}=20)$ was

$$
\text { egg number }=8721 \times \mathrm{BMI}-52818
$$

A homogeneity-of-slopes test showed that the 2 slopes for the relation between egg number and BMI were

Table 4. Analysis of variance for the effects of body mass (BMI) and type of data (field or experimentally collected) on egg number, and interaction between BMI and data type (common slope). ns: $p>0.05$

\begin{tabular}{|lcrrrc|}
\cline { 2 - 6 } $\begin{array}{l}\text { Source of } \\
\text { variation }\end{array}$ & $\begin{array}{c}\text { SS } \\
\left(\times 10^{9}\right)\end{array}$ & df & $\begin{array}{c}\text { MS } \\
\left(\times 10^{9}\right)\end{array}$ & F-ratio & $p$ \\
\hline Type & 0.107 & 1 & 0.107 & 0.7 & ns \\
BMI & 3.740 & 1 & 3.740 & 24.7 & $<0.001$ \\
Type $\times$ BMI & 0.137 & 1 & 0.137 & 0.9 & ns \\
Error & 3.790 & 25 & 0.152 & & \\
\hline
\end{tabular}

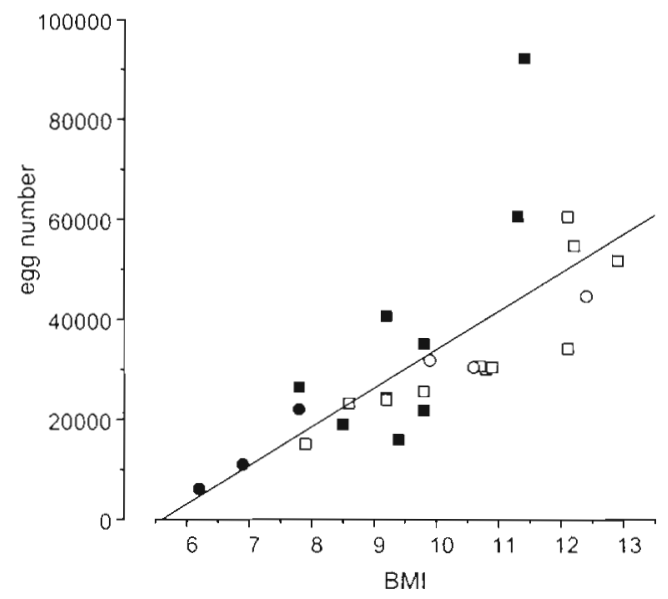

Fig. 3. Macoma balthica. Mean egg number produced by a standardized $M$. balthica (with a shell length of $15 \mathrm{~mm}$ ) in relation to body mass (BMI) values measured just prior to spawning. Origin of data: experimental data obtained in 1994 (a) and 1995 (a) by Honkoop \& Van der Meer (1997), and field-collected data in 1995 ( $)$ and $1996(0)$. BMI is ash-free dry mass divided by cubic shell length $\left(\mathrm{mg} \mathrm{cm}^{-3}\right)$. Line represents the best linear fit: egg number $=7739 \times \mathrm{BMI}-43314$

not significantly different between field and experiment data (Table 4). The common slope was significantly different from zero. The intercepts were again not significantly different between the field and laboratory collected data. So the regression lines for the field and the experiments were sufficiently similar $\left(F_{\mathrm{s}\{2,22\}}=0.5, \mathrm{p}>0.05\right)$ to calculate a single fit $\left(\mathrm{R}^{2}=\right.$ $0.54, p<0.001)$ :

$$
\text { egg number }=7739 \times \mathrm{BMI}-43314
$$

This equation predicts that if the BMI is smaller than $43314 / 7739=5.6$, no eggs are produced, whereas 7739 eggs are produced per BMI unit above the value of 5.6 . All data points, as well as the line defined by Eq. (6), are shown in Fig. 3.

\section{DISCUSSION}

\section{Stimulation of spawning}

Under natural conditions, the trigger initiating spawning is thought to be a rise in seawater temperature (Caddy 1967, De Wilde \& Berghuis 1976). We imitated this trigger using a temperature shock to adult animals collected in the field every week in early spring. Our specimens could be stimulated to spawn their eggs only during the 1 or 2 wk before natural spawning took place in the field. Although De Wilde \& Berghuis (1976) report a relatively early success in initiating spawning in the lab, we did not (or hardly did so) succeed in making Macoma balthica spawn more 
than 2 wk before natural spawning took place. This was also reported by Caddy (1967), who only succeeded in initiating spawning during the period of natural spawning. Therefore, it seems reasonable to suppose that spawning, initiated by means of a temperature shock, is only successful if animals are ripe and that 'artificially' spawned eggs show their mature size.

\section{Field observations}

After the mild winter of 1994-1995, body mass values at the 3 stations varied in the expected way, longer immersion times being linked with higher body mass values. This relationship has been shown earlier by Beukema et al. (1977) on the basis of field measurements and by Honkoop \& Beukema (1997) on the basis of experimentally collected data. In the latter publication it is also argued that (facultative) deposit feeders such as Macoma balthica can reduce part of their winter loss of body mass by the intake of detritus and/or benthic diatoms, which are present in winter, particularly at higher intertidal levels. Accordingly, both in the August 1994 to March 1995 period and in the August 1995 to March 1996 period, losses of body mass were lowest at the station ( $\operatorname{Stn} C$ ) that is situated highest in the intertidal area (Table 1). Due to the different characters of the 2 winters (the first was mild, the second was cold), i.e. because of the lower metabolic costs at lower temperatures, the loss of body mass was lower at all stations during the cold winter (1995-1996) than it was during the mild winter (19941995). Bayne \& Widdows (1978) argued that higher water temperatures cause a more negative scope for growth in the marine mussel Mytilus edulis. A lower loss of body mass at (artificially) lowered water temperatures during winter was indeed observed in $M$ edulis and also in 2 other bivalves, $M$. balthica and Cerastoderma edule (L.), by Honkoop \& Beukema (1997). It is therefore reasonable to suppose that differences in loss of body mass during the 2 winters were directly caused by differences in temperature. There is no evidence that feeding conditions are better in cold than in mild winters. Growth rates in $M$. balthica are primarily governed by diatom concentrations (Beukema \& Cadée 1991) and in winter these are not related to temperatures (G. C. Cadée pers. comm.). The higher August BMI values in 1995 (as compared to 1994) were probably caused by better feeding conditions during the spring-summer growing season and contributed strongly to the relatively high BMI at all 3 stations after the winter of 1995-1996 (as compared to the values observed after the winter of 1994-1995): a large part of the differences observed between years in March BMI (4.0 $\mathrm{mg} \mathrm{cm}^{-3}$ ) already existed in the preceding August $\left(2.8 \mathrm{mg} \mathrm{cm}^{-3}\right)$

Egg size at the 3 stations differed significantly (Fig. 1). Though the difference between the diameter of the smallest and largest eggs amounted to only about $8 \%$, it equals a considerable difference in egg volume (about $21 \%$ ). In accordance with the better feeding conditions (longer daily foraging times), higher growth rates, and higher body masses at the lower tidal levels (Beukema et al. 1977), eggs were largest at the lowest intertidal station. A more direct relationship between egg size and food availability was found in Canadian Macoma balthica populations, with somatic growth rates being higher and eggs being larger in areas where the chlorophyll content of the sediment was higher (Harvey et al. 1993).

In contrast to egg sizes (which were better correlated with August BMI values), egg numbers were significantly correlated with March BMI values (Fig. 2D). Final egg numbers to be spawned will be determined by both formation and resorption processes. Lack of food prior to the spawning period may be an important factor stimulating resorption. Resorption of gametes during gametogenesis, at relatively high water temperatures and in the absence of food, has been reported in the bivalves Mytilus edulis (Bayne et al. 1978, 1982, Pipe 1987) and Mya arenaria (Coe \& Turner 1938), but not yet in Macoma balthica, although in this species similar processes were reported in the period immediately after spawning (Caddy 1967, Gilbert 1978). Though no data appear to be available, resorption processes are plausible also in $M$. balthica. At European coasts at temperate latitudes, most $M$. balthica females have already been found to possess mature gonads a few months before spawning (Caddy 1967. Lammens 1967, Chambers \& Milne 1975, Madsen \& Jensen 1987, Bonsdorff \& Wenne 1989), although some other authors have reported this phase to be reached only just before spawning (De Wilde \& Berghuis 1976 , Gilbert 1978). Therefore, it is possible that eggs are resorbed during winter when food availability is low. As the annual minima of body mass values in $M$. balthica are found in February-March (Beukema \& De Bruin 1977), such resorption would continue until March, when food concentrations and $M$. balthica body mass rise again (Cadée 1978, Beukema \& Cadée 1996). In this way, a close correlation can arise between egg numbers and March BMI values.

\section{Shell-length and body-mass related reproductive output}

After testing the homogeneity of slopes between shell length and number of eggs produced, it was 
found that a significant relation existed between produced egg number and the third power of shell length. This provides a tool to recalculate egg number to apply to female Macoma balthica individuals with a standardized shell length of $15 \mathrm{~mm}$ and to compare fecundities between groups with different mean shell lengths. In this way it was possible to compare experimentally collected data (Honkoop \& Van der Meer 1997) with the field-collected data described in the present paper (Fig. 3).

To find evidence that immersion time and winter temperature can indeed influence egg numbers, experiments were performed in which immersion time and water temperature during the winter period were manipulated. In groups of Macoma balthica, body mass was measured prior to spawning (Honkoop \& Beukema 1997) and egg numbers were estimated (Honkoop \& Van der Meer 1997). The combination of these results with the field-collected data described in the present paper showed a causal relationship between both immersion time and water temperature and egg numbers. Thus both environmental factors controlled the fecundity of $M$. balthica populations and their effects were exerted via influences on body mass The highly significant relation between BMI prior to spawning and produced egg numbers (Table 4, Fig. 2D) provides a tool to predict egg number on the basis of the easily measurable BMI. This could make it possible to study relationships between egg production at the population level and subsequent recruitment. No eggs were produced if the BMI value became smaller than 5.6 (Fig. 3), indicating that this is a critical value, below which survival apparently becomes more important than the production of offspring.

\section{Life-history aspects}

Our results showed that egg size is correlated with body mass in August (Fig. 2A) and hardly correlated with body mass in March (Fig. 2B). This indicates that egg size is determined at an early stage during gametogenesis. Gonadal development in Macoma balthica takes place during a prolonged period, from early summer until the end of autumn or the beginning of wintes (Caddy 1967, Lammens 1967, Chambers \& Milne 1975, Pekkarinen 1983, Madsen \& Jensen 1987, Bonsdorff \& Wenne 1989, Harvey \& Vincent 1989, 1991), although some other authors have reported an even longer lasting gametogenesis, until just prior to spawning (De Wilde \& Berghuis 1976, Gilbert 1978). If the availability of food was high (Stns A and B), eggs larger than those produced in areas where availability of food was more marginal (Stn C) were produced. Experiments reported by Honkoop \& Van der Meer (1997) showed that egg size could not be influenced by manipulation of water temperature and immersion time during autumn and winter. This explains why the correlation between egg size and March BMI values was low (Fig. 2B).

Reproductive output consists of 2 components, egg size and egg number According to Smith \& Fretwell (1974), Roff (1992) and Stearns (1992), a trade-off between size and number exists and is lineage dependent. Within populations of the same species this trade-off is not always clear (Stearns 1992). This seems to be the case in Macoma balthica, where fewer and also smaller eggs were produced under relatively unfavourable conditions (short immersion times, low food availability, high energy demand). However there are some examples that this trade-off also holds in some other bivalve species. In 2 field populations of Mytilus edulis, one with a poor and one with a rich food supply during the period of gametogenesis, egg sizes were similar but the group without food produced fewer eggs (Bayne \& Worral 1980, Bayne et al. 1983) However, under stressful conditions $M$. edulis can also produce smaller eggs (Bayne et al. 1978). In the giant scallop Placopecten magellanicus food shortage resulted in low numbers of eggs of normal size (Barber et al. 1988). Thus, if food becomes limited, the latter 2 bivalve species generally decrease their fecundity (i.e. egg number), whereas egg size remains unchanged.

Acknowledgements. We thank Diana Kwast and Sylvia Klos for counting eggs and for their assistance in the spawning experiments, Jaap Zuidewind and Diana Kwast for collecting animals at the tidal flats, J. J. Beukema and Theunis Piersma for comments on earlier drafts of the manuscript. This is publication no. 3165 of NIOZ, Texel

\section{LITERATURE CITED}

Barber BJ, Getchell R, Shumway S, Schick D (1988) Reduced fecundity in a deep-water population of the giant scallop Placopecten magellanicus in the Gulf of Maine, USA. Mar Ecol Prog Ser 42:207-212

Bayne BL, Bubel A, Gabbott PA, Livingstone DR, Lowe DM, Moore MN (1982) Glycogen utilisation and gametogenesis in Mytilus edulis L. Mar Biol Lett 3:89-105

Bayne BL, Holland DL, Moore MN, Lowe DM, Widdows J (1978) Further studies on the effects of stress in the adult on eggs of Mytilus edulis. J Mar Biol Assoc UK 58:825-841

Bayne BL, Salkeld PN, Worrall CM (1983) Reproductive effort and value in different populations of the marine mussel Mytilus edulis L. Oecologia 59:18-26

Bayne BL, Widdows J (1978) The physiological ecology of two populations of Mytilus edulis L. Oecologia 59:137-162

Bayne BL, Worral CM (1980) Growth and production of mussels Mytilus edulis from two populations. Mar Ecol Prog Ser 3:317-328

Beukema JJ (1982) Annual variation in reproductive success and biomass of the major macrozoobenthic species living in a tidal flat area of the Dutch Wadden Sea. Neth J Sea Res 16:37-45 
Beukema JJ (1992) Expected changes in the Wadden Sea benthos in a warmer world lessons from periods with mild winters. Neth J Sea Res 30:73-79

Beukema JJ, Cadee GC (1991) Growth rates of the bivalve Macoma balthica in the Wadden Sea during a period of eutrophication: relationships with concentrations of pelagic diatoms and flagellates. Mar Ecol Prog Ser 68:249-256

Beukema JJ, Cadee GC (1996) Consequences of the sudden removal of nearly all mussels and cockles from the Dutch Wadden Sea. PSZN I: Mar Ecol 17:279-289

Beukema JJ, Cadée GC, Jansen JJM (1977) Variability of growth rate of Macoma balthica (L.) in the Wadden Sea in relation to availability of food. In: Keegan BF, O'Ceidigh $P$, Boaden PJS (eds) Proc 11th Europ Mar Biol Symp. Pergamon Press, New York, p 69-77

Beukema JJ, De Bruin W (1977) Seasonal changes in dry weight and chemical composition of the soft parts of the tellinid bivalve Macoma balthica in the Dutch Wadden Sea. Neth J Sea Res 11:42-55

Beukema JJ, Desprez M (1986) Single and dual growing seasons in the tellinid bivalve Macoma balthica. J Exp Mar Biol Ecol 102:35-45

Beukema JJ, Knol E, Cadée GC (1985) Effects of temperature on the length of the annual growing season in the tellinid bivalve Macoma balthica (L.) living on tidal flats in the Dutch Wadden Sea. J Exp Mar Biol Ecol 90:129-144

Bonsdorff $E_{1}$ Wenne R (1989) A comparison of condition indices of Macoma balthica (L.) from the northern and southern Balthic Sea. Neth J Sea Res 23:45-55

Brafield AE, Newell GE (1961) The behaviour of Macoma balthica (L.). J Mar Biol Assoc UK 41:81-87

Caddy JF (1967) Maturation of gametes and spawning in Macoma balthica (L.). Can J Zool 45:955-965

Cadée GC (1978) On the origin of organic matter accumulating on tidal flats of Balgzand, Dutch Wadden Sea. Hydrobiol Bull 12:145-150

Cadée GC, Hegeman J (1977) Distribution of primary production of the benthic microflora and accumulation of organic matter on a tidal flat area, Balgzand, Dutch Wadden Sea. Neth J Sea Res 11:24-41

Chambers MR, Milne H (1975) The production of Macoma balthica (L.) in the Ythan Estuary. Estuar Coast Mar Sci 3: $443-455$

Coe WR Turner HJ (1938) Development of the gonads and gametes in the soft-shelled clam (Mya arenaria). J Morphol 62:91-111

De Wilde PAWJ (1975) Influence of temperature on behaviour, energy metabolism, and growth of Macoma balthica (L.). In: Barnes $H$ (ed) Proc 9th Europ Mar Biol Symp, Aberdeen University Press, p 239-256

De Wilde PAWJ, Berghuis EM (1976) Laboratory experiments on the spawning of Macoma balthica: its implications for production research. In: McLusky DS, Berry J (eds) Physiology and behaviour of marine organisms. Pergamon Press, Oxford, p 375-384

Gilbert MA (1978) Aspects of the reproductive cycle in Macoma balthica (Bivalvia). Nautilus 92:21-24

Green RH (1973) Growth and mortality in an Arctic intertidal population of Macoma balthica (Pelecypoda, Tellinidae). J Fish Res Bd Can 30:1345-1348

Harvey M, Vincent B (1989) Spatial and temporal variations of the reproduction cycle and energy allocation of the bivalve Macoma balthica (L.) on a tidal flat. J Exp Mar Biol Ecol 129:199-217

Harvey M, Vincent B (1990) Density, size distribution, energy

This article was submitted to the editor allocation and seasonal variations in shell and soft tissue growth at two tidal levels of a Macoma halthica (1..) popullation. J Exp Mar Biol Ecol 142:151-168

Harvey M, Vincent B (1991) Spatial variability of lengthspecific production in shell, somatic tissue and sexual products of Macoma balthica in the Lower St. Lawrence Estuary. I. Small and meso scale variability. Mar Ecol Prog Ser 75:55-66

Harvey M, Vincent B, Gratton Y (1993) Spatial variability of length-specific production in shell, somatic tissue and sexual products of Macoma balthica in the Lower St. Lawrence Estuary. II. Large-scale variability. Mar Biol 115:421-434

Honkoop PJC, Beukema JJ (1997) Loss of body mass in winter in three intertidal bivalve species: an experimental and observational study of the interacting effects between water temperature, feeding time and feeding behaviour. J Exp Mar Biol Ecol (in press)

Honkoop PJC, Van der Meer J (1997) Experimentally induced effects of water temperature and immersion time on reproductive output of bivalves in the Wadden Sea. J Exp Mar Biol Ecol (in press)

Hummel H (1985) Food intake of Macoma balthica (Mollusca) in relation to seasonal changes in its potential food on a tidal flat in the Dutch Wadden Sea. Neth J Sea Res 19: $52-76$

Jensen KT (1992) Dynamics and growth of the cockle Cerastoderma edule, on an intertidal mud-flat in the Danish Wadden Sea: effects of submersion time and density. Neth J Sea Res 28:335-345

Kooijman SALM (1993) Dynamic energy budgets in biological systems. Cambridge University Press, Cambridge, p $53-76$

Kristensen I (1957) Differences in density and growth in a cockle population in the Dutch Wadden Sea. Arch Neerl Zool 12:351-453

Lammens JJ (1967) Growth and reproduction of a tidal flat population of Macoma balthica (L.). Neth J Sea Res 3: $315-382$

Madsen PB, Jensen K (1987) Population dynamics of Macoma balthica in the Danish Wadden Sea in an organically enriched area. Ophelia 27:197-208

Möller P, Rosenberg R (1983) Recruitment, abundance and production of Mya arenaria and Cardium edule in marine shallow waters, western Sweden. Ophelia 22:33-55

Olafsson EB (1986) Density dependence in suspension-feeding and deposit-feeding populations of the bivalve $\mathrm{Ma}$ coma balthica: a field experiment. J Anim Ecol 55:517-526

Pekkarinen M (1983) Seasonal changes in condition and biochemical constituents in the soft parts of Macoma balthica (Lamellibranchiata) in the Tvärminne brackish water area (Balthic Sea). Ann Zool Fenn 20:311-322

Pipe RK (1987) Ultrastructural and cytochemical study on interactions between nutrient storage and gametogenesis in the mussel Mytilus edulis. Mar Biol 96:519-528

Roff DA (1992) The evolution of life histories. Theory and analysis. Chapman \& Hall Inc, New York, p 242-346

Smith CC. Fretwell SD (1974) The optimal balance between size and number of offspring. Am Nat 108:499-506

Stearns SC (1992) The evolution of life histories. Oxford University Press, Oxford, $p$ 72-89

Zwarts L (1991) Seasonal variation in body weight of the bivalves Macoma balthica, Scrobicularia plana, Mya arenaria and Cerastoderma edule in the Dutch Wadden Sea. Neth J Sea Res 28:231-245

Manuscript first received: December 30, 1996

Revised version accepted: February 13, 1997 